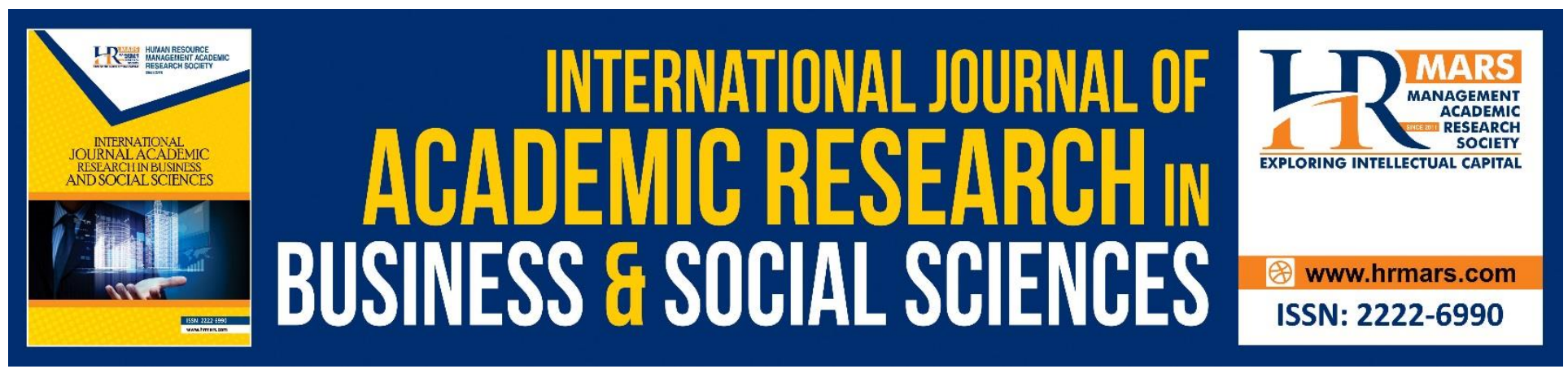

\title{
Library User Perception towards librarians in public library: A Malaysian Story
}

\author{
Syuhada Ali, Halida Yu and Noraizan Amran
}

To Link this Article: http://dx.doi.org/10.6007/IJARBSS/v8-i9/4604

DOI: $\quad 10.6007 /$ IJARBSS/v8-i9/4604

Received: 21 August 2018, Revised: 19 September 2018, Accepted: 29 September 2018

Published Online: 15 October 2018

In-Text Citation: (Ali, Yu, \& Amran, 2018)

To Cite this Article: Ali, S., Yu, L., \& Amran, N. (2018). Library User Perception Towards librarians in public library: A Malaysian story. International Journal of Academic Research in Business and Social Sciences, 8(9), 452463.

Copyright: (C) 2018 The Author(s)

Published by Human Resource Management Academic Research Society (www.hrmars.com)

This article is published under the Creative Commons Attribution (CC BY 4.0) license. Anyone may reproduce, distribute, translate and create derivative works of this article (for both commercial and non-commercial purposes), subject to full attribution to the original publication and authors. The full terms of this license may be seen

at: http://creativecommons.org/licences/by/4.0/legalcode

Vol. 8, No. 9, September 2018, Pg. 452 - 463

http://hrmars.com/index.php/pages/detail/IJARBSS

JOURNAL HOMEPAGE

Full Terms \& Conditions of access and use can be found at http://hrmars.com/index.php/pages/detail/publication-ethics 


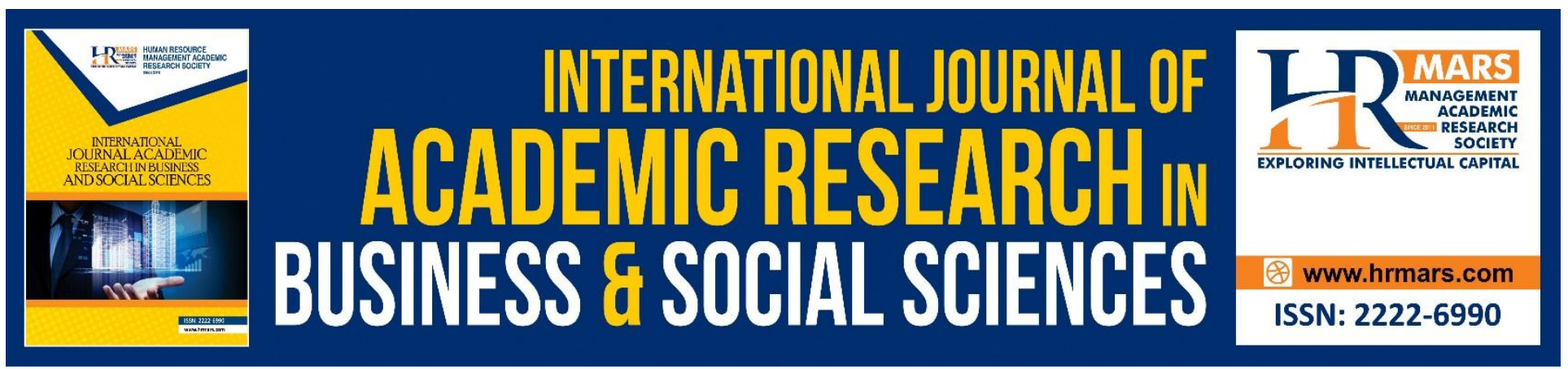

\title{
Library User Perception Towards librarians in public library: A Malaysian story
}

\author{
Syuhada Ali, Halida Yu and Noraizan Amran \\ Faculty of Information Management, Universiti Teknologi Mara, UiTM Selangor, \\ Malaysia
}

\begin{abstract}
This paper examines library users perceptions towards librarians in a public library in Selangor, Malaysia. The library users focus their observations in different scopes of the librarians such as the image, skill and nature of work. The findings from this study inform us whether library users have the same stereotype opinion towards librarians in public library. The study was conducted using the quantitative method and questionnaires were distributed to 383 library users in a public library in Selangor. This study examines library users' perception towards librarian in Perbadanan Perpustakaan Awam Selangor. Unlike the popular belief, the findings in this study refute the assumption that library users have negative views of librarians. The findings in this study show that the library users of the Perbadanan Perpustakaan Awam Selangor does have negative perception towards librarians.
\end{abstract}

Keywords: Information, Usefulness, Knowledge sharing, Enjoyment, Usage of social media

\section{INTRODUCTION}

In today's world of rapid information and technological growth, the information worker profession is at risk of becoming obsolete, particularly the librarians. Living in the globalization era where information is equal to money and power, we cannot deny the important role of the information professionals today to assist us in finding and using information to make important decisions in our lives (Nilsen \& McKechnie, (2002). Amidst the wealth of information offered to us every day, there comes new challenges to manage and to filter them before they are good for use. While each of us receives basic information literacy education most of us still lack of good information literacy mastery to seek, manage, and use information independently, Langridge, Riggi \& Schultz, (2014), hence, we need to turn to professional librarians for help. This is a strong point to say that librarians are still relevant in our modern lives today Bickley \& Corrall, (2011). Librarians still have important roles to offer to us. There are a lot of advantages in having librarians to manage data and information for us. A Librarian is one of the information professionals. He/she is a person who works professionally in a library, providing access to information and sometimes social or technical programming.

Traditionally, a librarian's tasks include organizing books on shelves, helping users to locate books, giving reference services to users, and becoming a reference guide. A librarian also used to be 
INTERNATIONAL JOURNAL OF ACADEMIC RESEARCH IN BUSINESS AND SOCIAL SCIENCES Vol. 8, No. 9, Sept. 2018, E-ISSN: 2222-6990 @ 2018 HRMARS

perceived negatively in the past. He/she was very popular among the book worms, and people in general use to see the librarian as an old women monitoring children in the library. This negative perspective is portrayed in books and magazines, as well as in the mass media.

Findings from previous studies reveal more negative perceptions on librarians (Nilsen \& McKechnie, (2002), Riggi \& Schultz, (2014). Among the common stereotypes are, librarians have undesirable appearance, personality, body language, and facial expression. They are often portrayed to be old ladies, wearing thick glasses, and have cruel expression, (Nilsen \& McKechnie, (2002). These reasons are enough to make library users stay away and refrain themselves from asking questions to the librarians. Fleck, I. \& Bawden, D. (1995) explained that the young library users in her study have these impressions of librarians' appearance and non-verbal behavior while attending to the library's reference desk. (as cited in Langridge, Riggi, \& Schultz, 2014). Young library users, especially children of primary (elementary) school age tend to think that librarians have the same character as their school discipline teachers. This is one of the reasons cited why children are quiet and well behaved in the library.

This study intends to investigate the perception of library users towards librarians, their working skills, as well as their nature of work. Past studies reveal the fact that many people tend to misunderstood librarians, their skills, and their work, (Fisher, 1988, Guzman et al., 2007, and Peresie \& Alexander, 2005). Despite the important roles of librarians in assisting the public, little is known about library users perceptions of the librarians and their work, particularly in developing countries like Malaysia. So this study intends to find out the answers to these questions.

\section{LITERATURE REVIEW}

Librarians have a long history of interest in finding out library users' perceptions towards them.

Even in the past research, the word "perception towards librarian" has attracted great interest among researchers. The library users perceptions can be divided into three general categories, namely; librarian's image perception, librarian's skill perception, and librarian's nature of work perception. When it comes to librarian's image, the public has various opinions and they can range from positive views to negative ones. Personality traits of a librarian can be separated into positive and negative personality (Fisher, 1988). Fisher highlighted that some of the positive traits of librarians were of a confident, reasonably social, and innovative person. As for the negative side, librarians were perceived to have low leadership qualities, resistant to change, conservative, fussy, and cowering behind a date stamp. Likewise, a study by De Guzman et al. (2007) which investigates the image of librarian among Filipino school pupils also found that the school pupils categorize librarians into positive and negative views, namely desirable and undesirable librarian. While the public perceive librarians to have both positive and negative traits, it is noted that most of the outlooks are inclined to the negative views. In the media and books, television shows and book authors often portray a librarian as a "spinster, cold, stern, timid, shy" but "intelligent, well-informed, and helpful"(Peresie \& Alexander, 2005). An early study by Leigh and Sewny (1960) suggested no single distinctive image of librarians, rather, a number of different images ranging from a scholarly and resourceful professional to a timid, plain-looking, middle-aged female stamping cards and collecting pennies for overdue books. Similarly, a study by Goulding et al. (1999) found that the image of a librarian as "particularly shy, introvert, insecure, strict, punctual and dull", and at the same time described as "reliable, serious and selfless". Hernon and Pastine (1977) found a librarian was described as a little old lady behind the desk, checking out or shelving books, filing cards, and keeping the library in order. These views can be approved with a study by Cowell (1980) which described the popular image of a librarian as a 
INTERNATIONAL JOURNAL OF ACADEMIC RESEARCH IN BUSINESS AND SOCIAL SCIENCES Vol. 8, No. 9, Sept. 2018, E-ISSN: 2222-6990 @ 2018 HRMARS

fussy old woman, myopic and repressed, brandishing or perhaps cowering behind a date-stamp, and surrounded by an array of notices which forbid virtually every human activity.

Other studies report on library users perceptions towards librarians' skills and professionalism. These studies attempt to find out how library users rate librarians' work performance in comparison with others from different professions. Harris and Sue-Chan (1988) studied the perceptions of public library users and university students of the work performed by librarians and lawyers. It was found that they underestimated librarians' level of involvement in administrative and technical tasks, whereas they exaggerated the skills involved in practicing law. In addition, both groups of subjects perceived lawyers to be significantly more intelligent than librarians. It was not only the general public who did not adequately understand the role of librarians: even professionals from many other disciplines, depending heavily on libraries, failed to fully appreciate the contribution of librarians. In the same manner, A study by Fleck and Bawden (1995) investigated library users perceptions of legal and medical professionals and found out that librarians were considered as unambitious people, although as a whole, they were perceived as efficient, intelligent, enthusiastic, and cooperative. Meanwhile, Divay et al. (1987) reported that students, as library users also viewed librarians primarily in a service role within the university and put a positive image on the usefulness of librarians and valued their expertise but did not perceive them to have management, teaching, or research responsibilities.

With regards to library users perception towards librarian's nature of work

Studies by Fagan (2003) and Hernon \& Pastine, (1977)have found that students most frequently described librarian duties in academic libraries in relation to reference and circulation duties. Very few students in these studies appeared to recognize that academic librarians also have a teaching or instructional role (Fagan, 2003; Hernon \& Pastine, 1977). However, Polger and Okamoto (2010) found that $66 \%$ of the students in their sample perceived librarians as teachers. Although the study in Hernon and Pastine's (1977) study emphasized the role of librarian in helping them to locate resources, later studies found that academic librarians are not seen as a major source of academic assistance. It can be approved in a study by Chiu (2000) that a librarian becomes the least likely person to provide useful help in comparison to their lecturers, teaching assistants, and classmates. This claim can also be supported by similar research done by Lo (2004) and Fagan (2003). In research setting in Canada, Nilsen and McKechnie (2002) found that users of public libraries were guessing their answers about the work of librarians. The researchers concluded that the misconceptions of the library work could be attributed to its hidden nature. In contrast to the findings above, Nzivo (2012) found that library services were perceived positively. The staff, in particular was perceived as efficient, friendly, knowledgeable, honest and supportive.

\section{RESEARCH MODELS}

Figure 1 shows the theoretical framework about the research topic regarding the library's user perception towards librarian. The figure consists of three independent variables and dependent variables. The image, skills and nature of work are the independent variables that influence the library's user perception towards librarian which is dependent variables. In this context of the study, perception towards librarian can be defined as an idea of the image of the librarian in all human perspective. This perception of the librarian can be measured through perception regarding librarians (Vassilakaki \& Moniarau-Papaconstantinou, 2016) and manner or attitude of the librarian(Vassilakaki \& Moniarau-Papaconstantinou, 2016). From the main dimension of perception regarding librarians, 
INTERNATIONAL JOURNAL OF ACADEMIC RESEARCH IN BUSINESS AND SOCIAL SCIENCES

Vol. 8, No. 9, Sept. 2018, E-ISSN: 2222-6990 @ 2018 HRMARS

there are several element that can be measured such function of the librarian itself. The questions of this element such as willing to provide services, willing to collaborate with others, accessible and open to change. As for the other main dimension of the manner/ attitude of the librarian, the element that available for this dimension is characteristic of the librarian such as the friendly, open minded and sporting.

The first independent variable is librarian's professional image. This variable can be defined as the picture or image captured by the students towards academic librarian. This image perception can be measured through the attire of the librarian (Langridge, Riggi \& Schultz, 2014) and ability of the librarian (Langridge, Riggi \& Schultz, 2014). The elements that can be scrutinized are i) attire that influence or impress library users, ii) attire that influence promotions, iii) attire that influence colleagues iv) attire that is approachable for library's users. Second main dimension which is ability of the librarian. There is element that can be measure which is helping library's users. Questions that may rise are such as librarians aid my advancement in my academic discipline, librarian enable library's users to be more efficient in library's users academic pursuits, librarian help library's users distinguish between trustworthy and untrustworthy information and librarian provide students with the information skill that library's users need.

The second independent variable is librarian's professional skill perception. This includes the level of the librarian skill or educational level. This independent variable can be measured by skill of the librarian itself (Vassilakaki \& Moniarau-Papaconstantinou, 2016). These skills include, skills of the librarian itself and the elements are: i) social skill and ii) soft skill. These skills include communication skill, interpersonal skill, technology, teaching and leadership. The librarian nature of work perception is the last independent variable. It can be defined as originality of work or a duties of the librarian. This independent variable can be measured by job characteristic (Vassilakaki \& MoniarauPapaconstantinou, 2016) and duties of librarian (Bickley \& Corrall, 2011). The element of this dimension is characteristic of the work perform by the librarian. The librarian will be evaluated through responsibility, useful for the society, interesting, specialized, demanding, challenging, quite, focused on routine works and innovative. From second main dimension of duties of librarian, the elements that can be evaluated are duties or tasks perceived by library users. The duties or tasks that librarian do are putting books back on the shelve, finding books that students have reserved, helping library's users to find books, giving general directional help, buying book or periodical, looking after computer photocopier, processing fitness, security and removing outdated books. 


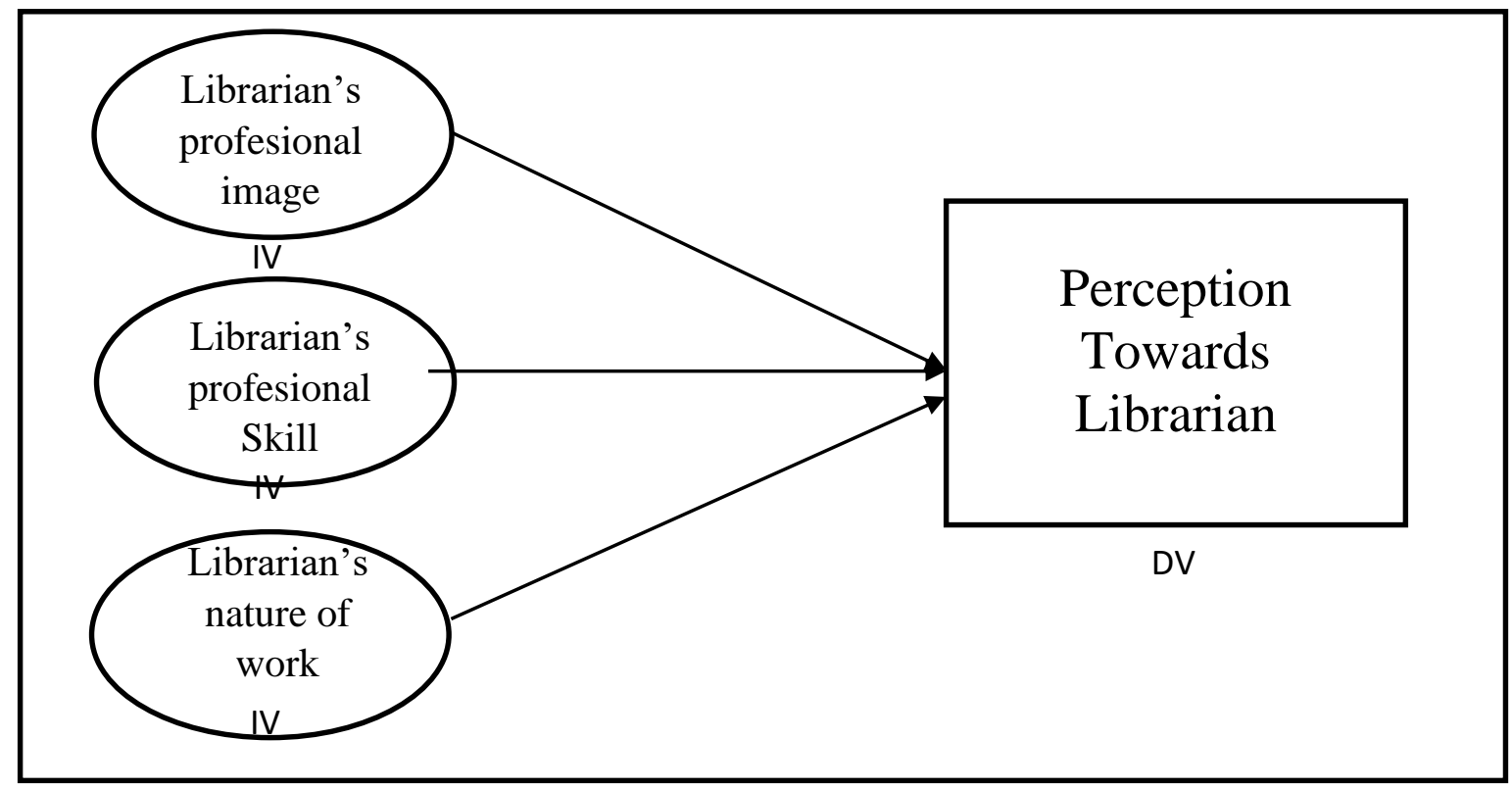

Figure 1: Theoretical Framework of Library's User Perceptions Towards Librarian in Perbadanan Perpustakaan Awam Selangor

\section{METHODOLOGY}

The key research questions in this study focuses on library's user at Perbadanan Perpustakaan Awam Selangor. The sampling frame consists of 901,371 total library's users from January 2017 until November 2017 at Perbadanan Perpustakaan Awam Selangor. The Raosoft Sample Size Calculator was used to calculate the sampling for Perbadanan Perpustakaan Awam Selangor. For this research to be conducted successfully and to ensure the validity of the data collected, the research needs to collect response data from 383 (the respondents) return sample from the population size. To achieve the sample size, the survey was sent to the respected respondents' size through face to face. A total of 383 questionnaires were distributed and 382 completed questionnaires were returned. The overall response rate for the survey was $87 \%$. An overview of data collection is given in Table 1 .

Table 1: Overview of Data Collection

\begin{tabular}{|l|l|}
\hline Questionnaire & Number \\
\hline Distributed & 383 \\
\hline Responded/ Returned & 382 \\
\hline Missing/ Unreturned & 1 \\
\hline Incomplete/ Rejected & 3 \\
\hline Valid responds & 379 \\
\hline Usable response rate & $\mathbf{8 7 \%}$ \\
\hline
\end{tabular}

\section{DATA ANALYSIS AND RESULT}

The purpose of this study is to identify the perception towards librarian among library's users in Perbadanan Perpustakaan Awam Selangor. This study also focuses on library user perception in different scopes of the librarian such as the image, skill and nature of work. The expectation 
INTERNATIONAL JOURNAL OF ACADEMIC RESEARCH IN BUSINESS AND SOCIAL SCIENCES Vol. 8, No. 9, Sept. 2018, E-ISSN: 2222-6990 @ 2018 HRMARS

outcome from this study to identify whether users have the same stereotype towards librarian in public library. The research objectives are:

1) To determine the relationship between library users perception and librarian's profesional image.

2) To identify the relationship between the library users perception and librarian's professional skill.

3) To measure the relationship between library users perception and librarian's nature of work.

In order to achieve the research objective, three research questions were proposed which are:

1) What is relationship between library users' perception and librarian's professional image?

2) What is relationship between library users' perception and librarian's professional skill?

3) What is relationship between library users' perception and librarian's nature of the work?

A number of 393 sets of questionnaires were distributed among library users at Perbadanan Perpustakaan Awam Selangor and 392 sets were collected and returned. The valid responden is 371 respondents, 114 (30.7\%) of them are male and 257 (69.3\%) are female respondents. Based on the data, approximately two third of the respondents are female respondents, while the male respondents consists of only one third of the study. In this research, the results of the acceptance level are influenced mostly on female perspective compare to male. As illustrated in Figure 2, the data findings are as such; the highest respondent are from 17 to 25 years old with 193 respondents.

Table 2: Statistics of Age

\begin{tabular}{|c|c|c|c|c|c|}
\hline & & Frequency & Percent & $\begin{array}{l}\text { Valid } \\
\text { Percent }\end{array}$ & $\begin{array}{l}\text { Cumulative } \\
\text { Percent }\end{array}$ \\
\hline \multirow[t]{6}{*}{ Valid } & $<17$ & 76 & 20.5 & 20.5 & 20.5 \\
\hline & $17-25$ & 193 & 52.0 & 52.0 & 72.5 \\
\hline & $26-40$ & 94 & 25.3 & 25.3 & 97.8 \\
\hline & $41-55$ & 4 & 1.1 & 1.1 & 98.9 \\
\hline & $>56$ & 4 & 1.1 & 1.1 & 100.0 \\
\hline & Total & 371 & 100.0 & 100.0 & \\
\hline
\end{tabular}

The profession variable has been constructed into four parts in the questionnaire which are students, day-job, self-employed and retire. 242 (65.2\%) respondents are students, 101 (27.2\%) are respondents in day-job, 21 (5.7\%) of respondents self-employed dan 7 (1.9\%) respondents are retiree. This is happened because majority of the respondents participate in the study are students. The race variable has been constructed into 3 groups which are Malay, Chinese and Indian. The highest number of participating respondents are Malay, 333 (89.8\%) and follows by Chinese, 30 (8.1\%) library's users. The other race is Indian, 8 respondents (22\%). This statistic is as such as the public library is located in Shah Alam, a predominantly Malay area. 
INTERNATIONAL JOURNAL OF ACADEMIC RESEARCH IN BUSINESS AND SOCIAL SCIENCES Vol. 8, No. 9, Sept. 2018, E-ISSN: 2222-6990 @ 2018 HRMARS

All items from all constructs under study were entered for analysis and constrained to single factor. The results show that the single factor explained only $16.001 \%$ of the total variance, hence suggesting that the collected data is free from the threats of common method variance. Other data analyses that had been done in this chapter are:-

- Cronbach Alpha

The acknowledged Cronbach alpha incentive for real review is 0.7 (Saunders, Lewis, and Thornhill, 2009). Reliabilities under 0.60 are thought to be poor, those in the 0.70 good, adequate, and those more than 0.80 great (Sekaran and Bougie, 2003).

\begin{tabular}{|r|r|}
\hline Factors & Cronbach Alpha Values \\
\hline Librarian's profesional image & 0.694 \\
\hline Librarian's profesional Skill & 0.866 \\
\hline Librarian's nature of work & 0.763 \\
\hline Perception towards Librarian & 0.639 \\
\hline
\end{tabular}

- Exploratory Factor Analysis (EFA)

The exploratory factor analysis using Kaiser-Meyer-Olkin Measure of Sampling Adequacy in this research is greater than 0.6 which is 0.679 and the significance value is less than 0.05 which is 0.0. If the $p$ value is less than 0.05 , it indicates the data for this study is suitable for factor analysis.

- Descriptive Statistics

\section{Library's Users Perception Towards Librarian Image Variables:}

The results in the data show that library users perceptions concerning the attire and ability of the librarian, (library users perception of librarians' professional attire) is ( $M=4.11, S D=0.531$ ). Librarian ability to provide information to library users) is $(M=4.05, S D=0.705)$. In addition to it, facial expression of the librarian/ how approachable the librarian is to library users is $(M=4.08, S D=0.634)$. With regards to librarian's attire to influence library users to approach or make in-contact with the librarian is $(M=4.05, S D=0.678)$. Library's users also perceive librarian's ability to help them to distinguish trustworthy information from untrustworthy one is at $(M=4.05, S D=0.589)$. In addition, the library users perception of the librarian's image as a factor of consideration to approach the librarian is at $(M=3.98, S D=0.707)$. The library users perception of the librarian attire affect the library users personnel interaction is $(M=3.92, S D=0.713)$. The last variable is library user perception towards librarian helping library users related to assignment $(M=3.83, S D=0.840)$.

\section{Library's Users Perception Towards Librarian Skill Variables:}

The first element is library users perception of how good the librarian is at teaching library users ( $M=$ $4.15, S D=0.641$ ). Second element is the library users perception of the librarian communication skills with the library users $(M=4.10, S D=0.500)$. The third element is the library users perception of the way librarians try to solve problem with regards to the library users references sources $(M=4.05, S D=$ 0.624). The fourth element is the library users perception of librarian skill in guiding and teaching the library users in searching information $(M=4.02, S D=0.649)$. The fifth element is the library users perception of librarian skills with regards to commitment in learning something new $(M=4.02, S D=$ 0.645). The next element is the library users perception of librarian skills with regards to leadership skill ( $M=3.96, S D=0.696)$, and lastly, library users perception of librarian skill in promoting their roles $(\mathrm{M}=3.95, \mathrm{SD}=0.643)$. 
INTERNATIONAL JOURNAL OF ACADEMIC RESEARCH IN BUSINESS AND SOCIAL SCIENCES Vol. 8, No. 9, Sept. 2018, E-ISSN: 2222-6990 @ 2018 HRMARS

\section{Library's Users Perception Towards Librarian Nature of Work Variable:}

The results of the data also inform on library users perception of the nature of librarian's work. This includes the duties of the librarian, characteristic of the librarian's task and librarian attitude towards their work. The first library's users perception is in terms of how useful the nature of librarian's work is to the society $(M=4.31, S D=0.568)$. Secondly is the library users perception of the librarian's willingness to collaborate with others $(M=4.24, S D=0.557)$. Thirdly, the library users perception of the librarian's willingness to provide services $(M=4.22, S D=0.591)$. Fourthly, the library users perception of the librarian's flexibility to adjust to new conditions ( $M=4.20, S D=0.557)$. Fifthly, the library users perception of the librarian's duties to serve the public ( $M=4.17, S D=0.619)$. Other than that, the library users perception of useful is the librarian work's to the society $(M=4.16, S D=0.816)$. Beside that, the library users perception of the librarian's duties to check in and out library material $(M=4.16, S D=0.676)$. Other elements include: library users perception of how accessible librarians are to users $(M=4.16, S D=0.572)$, perception of how isolated librarians are in technology $(M=4.13$, $\mathrm{SD}=0.780$ ); perception of librarian's duties which is to buy books, journals and electronic material $(M=4.08, S D=0.710)$; perception on how interesting librarian's work is $(M=4.05, S D=0.822)$; perception of librarian's duties is to shelve books $(M=4.05, S D=0.783)$; perception on organizing events for the library $(M=4.00, S D=0.757)$; perception on librarians are outdated in technological development $(M=3.87, S D=0.958)$; and boring job $(M=3.70, S D=1.019)$. Based on the attitude towards work, library users perceive the librarians as very strict to library users $(M=3.95, S D=0.948)$. Last element is the library users perception that librarian's job routine is easy to do $(M=3.52, S D=$ 1.133).

\section{Library Users Perception Towards Librarian Variables:}

The results of the data shows that library users often use a library $(M=2.68, S D=0.864)$. The purposes of library users going to the library are as follows: for reading newspaper purposes $(M=1.77 \mathrm{SD}=$ $0.424)$; borrowing books $(M=1.66, S D=0.493)$; references purposes $(M=1.39, S D=4.99)$, and for study purposes $(M=1.34, S D=0.475)$. The library users also come in-contact with librarian during visit the library $(M=1.92, S D=0.336)$. Normally library users come in-contact with librarian to ask about events $(M=1.73, S D=0.446)$. The second and third reason why library's users come in-contact with librarian is to make payment for fines $(M=1.64, S D=0.479)$ and to borrow the book $(M=1.58, S D=$ 0.493 )at the circulation counter. Other reasons of library users going to library are: to ask about book $(M=1.46, S D=0.530)$; to ask about references $(M=1.37, S D=0.484)$ and lastly to ask about library services $(M=1.23, S D=0.421)$.

- Correlation Analysis and Multiple Regressions Analysis

Correlation data define the negative relationship between library users' perception and librarian's profesional image at Perbadanan Perpustakaan Awam Selangor with the Pearson Correlation value is $r=-0.180$ that indicates the two variables have not relationship. The finding reveal that the librarian at Perbadanan Perpustakaan Awam Selangor have good image viewed by the library users. The research finding refutes the indictment with the past literature that librarian image always look like fussy old woman, shy and introvert (Cowell, 1980; Goulding et al., 1999).

In addition, it also show the negative relationship between the library users' perception and librarian's professional skill at Perbadanan Perpustakaan Awam Selangor with the Pearson Correlation value is $r=-0.160$ that indicates the two variables have no relationship. Furthermore the finding reveal that librarian at Perbadanan Perpustakaan Awam Selangor have shown good profesional skills towards 
INTERNATIONAL JOURNAL OF ACADEMIC RESEARCH IN BUSINESS AND SOCIAL SCIENCES

Vol. 8, No. 9, Sept. 2018, E-ISSN: 2222-6990 @ 2018 HRMARS

library users. The past literatures recommend that information professionals need to maintain the positive image that currently public library users obtain but also work on promoting further their service and user-oriented tasks and characteristics, as well as their leadership skills (Vassilakaki and Moniarou-Papaconstantinou, 2016).

The data analysis show the negative relationship between library users' perception and librarian's nature of the work with the Pearson Correlation value is $r=-0.059$ that indicates the two variables have no positive relationship. This study proves that the librarian duties is not boring and the library's users understand that the librarian duties are to serve the community. The research findings are significantly supported by other literature (Hernon and Pastine, 1977; Fagan, 2003; Vassilakaki and Moniarou-Papaconstantinou, 2016). To conclude, based on the discussion above, the findings of this research are:

\section{H1: There is a low perception of librarian image among library users at Perbadanan Perpustakaan}

Awam Selangor is not supported.

H2: There is a low perception of librarian skill among library users at Perbadanan Perpustakaan Awam Selangor is not supported.

H3: There is a low perception of librarian nature of work among library's users at Perbadanan Perpustakaan Awam Selangor is not supported.

To conclude, the library users of the Perbadanan Perpustakaan Awam Selangor does have negative perception towards librarians. It can be approved with the analysis that have been conducted towards them and the hypothesis have been rejected.

\section{DISCUSSION ANS RECOMMENDATION}

The result of the $\mathrm{H} 1$ in this research cannot be accepted because of the research by Nzivo (2012) revealed that library users perceived staff in Kenyan public libraries as effective, friendly and supportive. The result of the $\mathrm{H} 2$ in this research can be accepted because as been mentions before variable for library's profesional skill have seven question. Based on descriptive statistic, library users agree that librarians at Perbadanan Perpustakaan Awam Selangor have good skills. The result of the $\mathrm{H} 3$ in this research can be accepted because as mentioned in a study by Vassilakaki and MoniarouPapaconstantinou (2016), the authors argue that the overall findings show positive image for librarian's status duties and performed work.

This finding is hope to allow librarians to gain more positive perception from library users from three variable that have been study in this research. The first recommendation for improvement or development of the librarian's profesional image is Perbadanan Perpustakaan Awam Selangor can create a cooperate video that focuses only on librarian. Librarians have always been portrayed with negative stereotype which is an older, single, white woman, generally accoutered with one or more of the following, cardigan, pearls, tweed skirt, hair in a bun and spectacles perched on the nose. So in order to break the negative stereotype or perception about image towards librarian Perbadanan Perpustakaan Awam Selangor can cooperate with National Library of Malaysia to make proposal to do the video and released it to all government broadcasting. Second recommendation for librarian profesional skill is Perbadanan Perpustakaan Awam Selangor can send librarians for professional training to improve their skill in order to better serve the community. The administration department 
INTERNATIONAL JOURNAL OF ACADEMIC RESEARCH IN BUSINESS AND SOCIAL SCIENCES

Vol. 8, No. 9, Sept. 2018, E-ISSN: 2222-6990 @ 2018 HRMARS

of Perbadanan Perpustakaan Awam Selangor can allocate more budget for librarians to attend workshops for professional development, such as soft skill, technical skill, communication skill, leadership skill, teaching skill, among others.

\section{FUTURE RESEARCH AND CONCLUSION}

The recommendation for future research in this study is important to help other researchers organize and develop their research structure to cover some other important aspects of perceptions towards librarian. Further study should be done as there are other issues emerging along with the rapid technological development. Librarians need to prepare themselves for the future by equipping themselves with knowledge and skills to serve the community.

\section{REFERENCES}

Bickley, R., \& Corrall, S. (2011). Student perceptions of staff in the Information Commons: a survey at the University of Sheffield. Reference Services Review, 39(2), 223-243. https://doi.org/10.1108/00907321111135466

Crawford, J. C., \& Lumpkin, J. R. (1983). The choice of selling as a career. Industrial Marketing Management, 12(4), 257-261. https://doi.org/10.1016/S0019-8501(83)80005-4

De Guzman, A., Custodio, S.M.B. \& Garcia, M.A.P. (2007). Surfacing Filipino school children's images of librarians through doodling. Libri, 57(1), 9-16.

Divay, G., Ducas, A.M. \& Michaud-Oystryk, N. (1987). Faculty perceptions of librarians at the University of Manitoba. College and Research Libraries, 48(1), 27-35.

Doskatsch, I. (2003). Perceptions and perplexities of the faculty-librarian partnership: an Australian perspective. Reference Services Review, 31(2), 111-121. https://doi.org/10.1108/00907320310476585

Fagan, J., \& Fagan, J. (2016). Students Perceptions of Academic Librarians Students. Perceptions of Academic Librarians, 3877(January). https://doi.org/10.1300/J120v37n78

Fisher, D.P. (1988). Is the librarian a distinct personality type?, Journal of Librarianship, 20 (1), 36-47.

Fleck, I. \& Bawden, D. (1995). The information professional: attitude and images. Examples from information services in law and medicine. Journal of Librarianship and Information Science, 27(4), 215-26.

Harris, R. \& Sue-Chan, C. (1988). Cataloging and reference, circulation and shelving: public library users and university students' perceptions of librarianship. Library and Information Science Research,10(1), 95-107.

Harris, R., \& Wilkinson, M. A. (2004). Situating gender: students' perceptions of information work. Information Technology \& People, 17(1), 71-86. https://doi.org/10.1108/09593840410522189

Hernon, P. \& Pastine, M. (1977). Student Perceptions of Academic Librarians, College and Research Libraries, 38(2),129-39.

Langridge, M., Riggi, C., \& Schultz, A. (2014). Student Perceptions of Academic Librarians The Influence of Pop Culture and Past Experience. The Librarian Stereotype: Deconstructing Perceptions \& Presentations of Information Work, 229-255. Retrieved from http://www.alastore.ala.org/detail.aspx?ID=11057

Leigh, R.D. \& Sewny, K.W. (1960). The popular image of the library and the librarian. Library Journal, 85, 2089-91. 
INTERNATIONAL JOURNAL OF ACADEMIC RESEARCH IN BUSINESS AND SOCIAL SCIENCES

Vol. 8, No. 9, Sept. 2018, E-ISSN: 2222-6990 @ 2018 HRMARS

McFadden, K. (2000). Overdue: an investigation and exploration of Grade 10 students' perceptions of a teacher-librarian. Retrieved from www.collectionscanada.gc.ca/obj/s4/f2/ dsk3/ftp04/mq52927.pdf

Nilsen, K. \& McKechnie, L. (2002). Behind closed doors: an exploratory study of the perceptions of librarians and the hidden intellectual work of collection development in Canadian public libraries. The Library Quarterly, Retrieved from www.jstor.org/stable/10.2307/40039761.

Nzivo, C. (2012). User perception on library services and information resources in Kenyan public libraries. Library Review, 61(2), 110-127.

Ole Pors, N. (1992). The education of librarians and the labour market. New Library World, 93(4), EUM0000000002425. https://doi.org/10.1108/EUM0000000002425

Peresie, M. \& Alexander, L.B. (2005). Librarian stereotypes in young adult literature. Young Adult Library Services. 4(1), 24-31.

Petr, K., \& Aparac-Jelusic, T. (2002). Public perception of the role and tasks of library and information science professionals in Croatia : an overview of recent activities. New Library World, 103(10), 364-375. https://doi.org/10.1108/03074800210447677

Polger, M. A., \& Okamoto, K. (2010). Can't Anyone Be a Teacher Anyway?: Student Perceptions of Academic Librarians as Teachers. Library Philosophy \& Practice, 1-16. https://doi.org/1522-0222

Polger, M. A., \& Okamoto, K. (2010). CUNY Academic Works \&quot;Can't anyone be a teacher anyway?\&quot;: Student Perceptions of Academic Librarians as Teachers \&quot;Can't Anyone Be a Teacher Anyway?\&quot;: Student Perceptions of Academic Librarians as Teachers. City University of New York (CUNY) Library Philosophy and Practice, 1-16. Retrieved from http://academicworks.cuny.edu/jj_pubs

Pors, N. O. (1994). The Changing Labour Market of the Information Professional Challenges for Library School Education. Librarian Career Development, 2(3), 14-21. https://doi.org/10.1108/09680819410066930

Rothwell, A. (1990). the Image of Librarians. Library Management (Vol. 11). https://doi.org/10.1108/01435129010005685

Vassilakaki, E., \& Moniarou-Papaconstantinou, V. (2016). How public library users perceive the information professional: is the image transforming? New Library World, 117(7/8), 449-463. https://doi.org/10.1108/NLW-11-2015-0090 